\title{
Multiple Variations of the Branches of the Brachial Plexus with Bilateral Connections between Ulnar and Radial Nerves
}

\author{
Múltiples Variaciones de los Ramos del Plexo Braquial con \\ Conexiones Bilaterales entre los Nervios Ulnar y Radial \\ Nasirudeen Oladipupo Ajayi; Lelika Lazarus \& Kapil Sewsaran Satyapal
}

AJAYI, N. O.; LAZARUS, L. \& SATYAPAL, K. S. Multiple variations of the branches of the brachial plexus with bilateral connections between ulnar and radial nerves. Int. J. Morphol., 30(2):656-660, 2012.

SUMMARY: During routine dissection of the upper limbs of a Caucasian male cadaver, multiple variations of the branches of the brachial plexus were observed. On the left side, the musculocutaneous nerve was absent and the muscles of the anterior compartment of the arm were innervated by the median nerve. The median nerve was also formed from three roots viz; two from the lateral and one from the medial cord of the brachial plexus. On the right side, the musculocutaneous nerve contributed a long communicating branch to the median nerve in the distal half of the arm. There were also communicating branches between the ulnar and radial nerves in both limbs at the humeral level. The co-existence of these variations appears to be unique and has not been reported in the literature reviewed. The anatomic and clinical significance of these variations is discussed.

KEY WORDS: Brachial plexus; Variations; median nerve; Musculocutaneous nerve; Ulnar nerve; Radial nerve; Communication.

\section{INTRODUCTION}

The variation in the formation, course and distribution of the brachial plexus branches are not uncommon and are reported by many authors (Pohlman 1908; Linell, 1921; Aktan et al., 2001; Pandey \& Shukla, 2007). Several studies have reported variations in the anatomy and communications between the branches of the medial and lateral cords (Le Minor, 1990; Kosugi et al., 1992; Yang et al., 1995; Venieratos \& Anagnostopoulou, 1998; Choi et al., 2002; Loukas \& Aqueelah, 2005) but there is paucity of literature on the communication between the medial, lateral and posterior cords. From the literature reviewed, only one case of a unilateral connection between the radial and ulnar nerves at high humeral level (just distal to the axillary artery) was reported with other brachial plexus branches having the classical pattern. Bilateral connection between ulnar and radial nerves at the humeral level has not been previously described in the medical literature.

\section{CASE REPORT}

During routine cadaveric dissection at the Department of Clinical Anatomy, University of KwaZulu-Natal, Durban,
South Africa, an anomaly of the median and musculocutaneous nerves with associated bilateral connections between the radial and ulnar nerves was incidentally observed in an adult male cadaver. The brachial plexus and the branches of its cords in the axilla and arm were dissected. The course and branches of the median, musculocutaneous, radial and ulnar nerves in the arm were noted. Variations from the classical pattern of formation and branching in the arm were documented.

On the right side, the musculocutaneous nerve gave a large and long communicating branch to the median nerve before piercing the coracobrachialis muscle (Fig. 1). The communicating branch joined the median nerve at the distal third of the humerus. There was also a communicating branch between the ulnar and radial nerves at the mid humeral level (Fig. 2).

On the left side, the musculocutaneous nerve was absent and the median nerve was formed by the fusion of three roots viz. two from the lateral cord and one from the medial cord of the brachial plexus (Fig. 3). Immediately after the first lateral root exited from the left the lateral cord, the second lateral root gave a branch to coracobrachialis and 
prior to joining the median nerve it gave the branches to biceps brachii and brachialis muscles (Fig. 3). The branch to brachialis muscle continued as the lateral cutaneous nerve of the forearm after supplying the muscle. The ulnar and

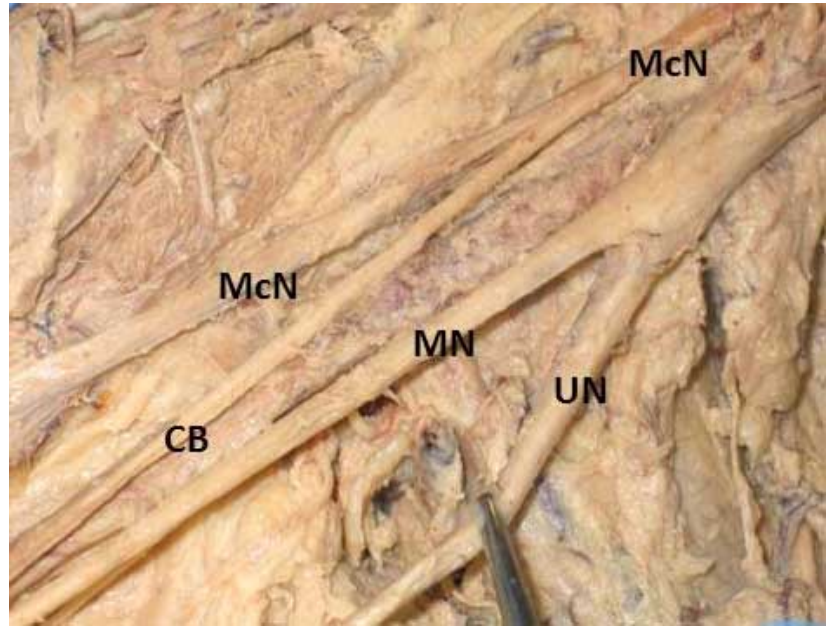

Fig. 1. Superior view of right upper limb illustrating communication between musculocutaneous and median nerves. McN. Musculocutaneous nerve; MN. Median nerve; UN.Ulnar nerve; CB. Communicating branch.

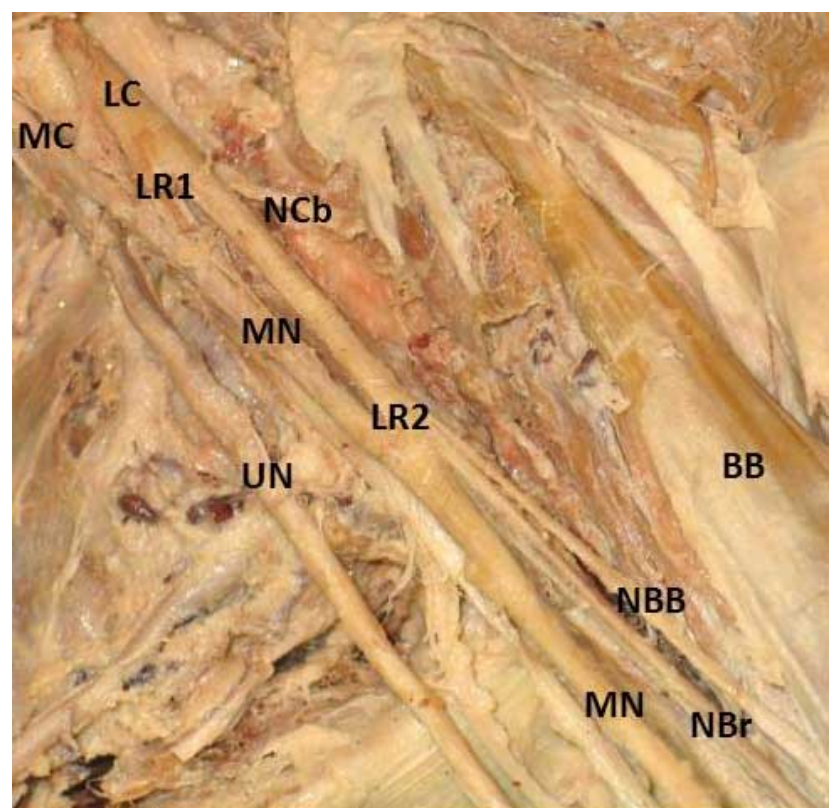

Fig. 3. Superior view of left upper limb illustrating formation of median nerve by three roots with muscular branches from the second lateral root. Note the absence of the musculocutaneous nerve. MC. Medial cord; LC. Lateral cord; LR1. First lateral root of median nerve; LR2. Second lateral root of median nerve; MN. Median nerve; UN. Ulnar nerve; $\mathrm{NCb}$. Nerve to coracobrachialis muscle; BB. Biceps brachii muscle; NBB. Nerve to biceps brachii muscle; NBr. Nerve to brachialis muscle. radial nerves were initially observed to run in the same sheath and after careful separation of the nerves, multiple communicating branches were observed between the two nerves (Fig. Fig. 2B).
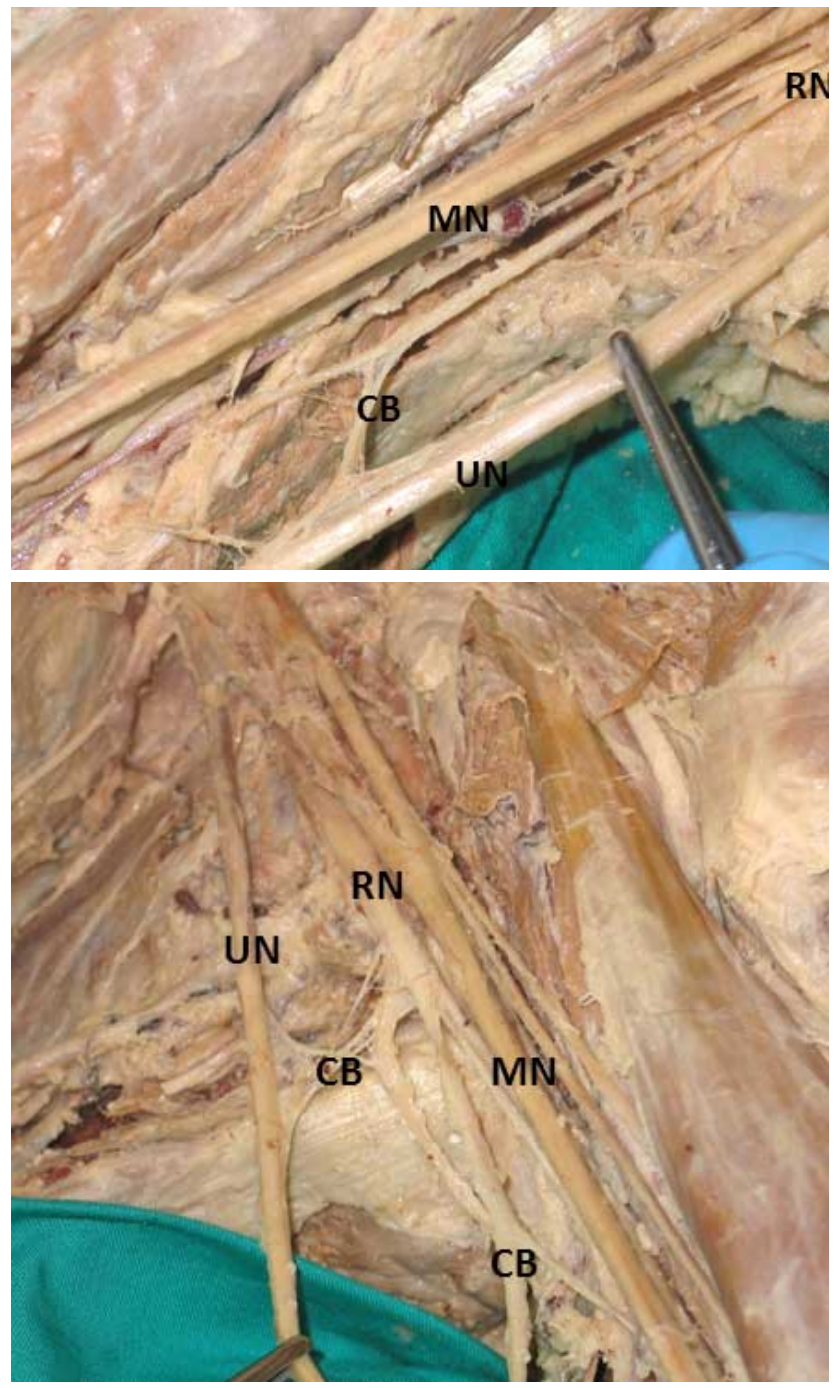

Figs. 2. Superior view of right (2A) and left (2B) upper limb illustrating communication between radial and ulnar nerves. MN. Median nerve; RN. Radial nerve; UN. Ulnar nerve: CB. Communicating branch.

\section{DISCUSSION}

The knowledge of variations in anatomy is invaluable in clinical practice, especially in radiological diagnoses and surgical procedures. It is often used in the explanation of non-classical clinical signs and symptoms (Loukas et al., 2008a). This case report shows multiple variations in the branches of the brachial plexus. Alton \& 
Huten (1977) said that all nerves of the brachial plexus are formed in two planes viz. anterior and posterior. The anterior planes comprise of nerves of the medial and lateral cords. Communication and variations are frequently seen within this plane and may involve either the formation of the medial and lateral cords or communications between their branches (Venieratos \& Anagnostopoulou, 1998).

The variations in the course and distribution of the musculocutaneous nerve have been reported previously (Venieratos \& Anagnostopoulou, 1998; Choi et al., 2002; Loukas \& Aqueelah, 2005; Guerri-Guttenberg \& Ingolotti, 2009; Kervancioglu et al., 2011). It may communicate with the median nerve in the arm (Sunderland et al., 1959; Chiarapattanakom et al., 1998; Venieratos \& Anagnostopoulou; Choi et al., 2002; Saeed \& Rufai, 2003) or be may be absent (Nakatani et al., 1997; Prasada-Rao \& Chaudhary, 2001; Nayak, 2007).

In this case report on the right side, the musculocutaneous nerve gave a communicating branch that joined the median nerve at the distal third of the arm; the former nerve thereafter pierced the coracobrachialis muscle. On the left side, the musculocutaneous nerve was absent; the branches to the coracobrachialis, biceps brachii and brachialis muscles were all from the second lateral root of the median nerve. The complete absence of the musculocutaneous nerve and the assumption of its innervation by the median nerve is uncommon (PrasadaRao \& Chaudhary, 2001). The most frequent variations of the brachial plexus are communications between the musculocutaneous and median nerves (Venieratos \& Anagnostopoulou). Embyologically, the musculocutaneous nerve is said to arise from the median nerve and the frequently observed communication between the two nerves is attributed to their common origin (Uyaroglu et al., 2008). The knowledge of this possible communication is important in traumatology of the shoulder joint, axillary repair operations, radical neck dissections, and in the management of fracture of the surgical neck of the humerus (Saeed \& Rufai, 2003). These communicating branches may also complicate the anterior surgical approach to the shoulder joint and if the surgeon needs to isolate and trace the median and/or the musculocutaneous nerve distally, the patient may have a median nerve deficit post-operatively if a present communication between them is stripped off and only the main nerve is saved (Venieratos \& Anagnostopoulou).

The median nerve is usually formed lateral to the axillary artery by the union of two roots each from the medial and lateral cords. There are several reports documenting variations in the formation of the median nerve. Tsikaras et al. (1983) reported absence of the C8 and $\mathrm{T} 1$ spinal nerve fibers in the median nerve, while some authors found additional roots. It is sometimes formed by the union of three roots viz. a medial and two lateral roots (Sargon et al.,1995; Saeed \& Rufai, 2003; Das \& Paul, 2005) or four roots viz. a medial and three lateral (Uzun \& Seelig, 2001). The median nerve has also been reported to be formed medial to the axillary artery (Das \& Paul; Pandey \& Shukla).

The median nerve on the right side was formed by two roots but received a long and large communicating branch from the musculocutaneous nerve at the distal third of the arm. The left median nerve was formed by three roots viz. two lateral and one medial root. On the left side, the second lateral root of the median nerve innervated the muscles of the anterior compartment of the arm. Ischemic pain or variable arterial insufficiency may result due to occlusion of the axillary artery by the variant lateral root of the median nerve during certain postural maneuvers of the shoulder joint (Saeed \& Rufai, 2003).

The ulnar and radial nerve on the right side had a single communicating branch whereas on the left side, there were multiple communication twigs between the two nerves at the mid humeral level. Although, there are reports of communications between the radial and ulnar nerves on the dorsal surface of the hand (Loukas et al., $2008 \mathrm{~b}$ ) including the cutaneous innervation of the ulnar dorsum of the hand by the radial nerve (Leis \& Wells, 2008), there are no reports of bilateral communication between the ulnar and radial nerves at the humeral level from the literature reviewed. The communication between branches of the medial and posterior cords at the humeral level is a rare variation of the brachial plexus.

The median and ulnar nerves carry most of the sympathetic supply to the upper limb (Pick, 1970) and the communication between branches of the brachial plexus could complicate the management of conditions such as complex regional pain syndrome.

Variation in nerves with abnormal origin, course, and distribution are usually more prone to iatrogenic injuries and entrapment neuropathies (Roberts, 1992). Failure to recognize these variations can also confound the assessment of the severity of nerve injury as well as recovery (Leis \& Wells, 2008). These communications can cause inappropriate nerve blockade and/or blockade of unexpected regions during anaesthesia. The understanding of possible variations will also aid proper diagnosis of sensorimotor symptoms (Pontell et al., 2011). 
AJAYI, N. O.; LAZARUS, L. \& SATYAPAL, K. S. Múltiples variaciones de los ramos del plexo braquial con conexiones bilaterales entre los nervios ulnar y radial. Int. J. Morphol., 30(2):656-660, 2012.

RESUMEN: Fueron observadas durante una disección de rutina de los miembros superiores de un cadáver caucásico masculino, múltiples variaciones de los ramos del plexo braquial. En el lado izquierdo, el nervio musculocutáneo estaba ausente y los músculos del compartimento anterior del brazo estaban inervados por el nervio mediano. El nervio mediano se encontraba formado de tres raíces dos provenientes del fascículo lateral y uno del fascículo medial del plexo braquial. En el lado derecho, en la mitad distal del brazo, el nervio musculocutáneo generó un largo ramo comunicante con el nervio mediano. Además, en el brazo, en ambos miembros superiores existían ramos comunicantes entre los nervios ulnar y radial. La coexistencia de estas variaciones aparece ser única y no ha sido relatada en la literatura consultada. Son discutidas la significancia anatómica y clínica de estas variaciones.

PALABRAS CLAVE: Plexo braquial; Variaciones; Nervio mediano; Nervio musculo cutáneo; Nervio ulnar; Nervio radial; Comunicación.

\section{REFERENCES}

Alnot, J. Y. \& Huten, B. La syste’ matisation du plexus brachial. Rev. Chir. Orthop., 63:27-34, 1977.

Aktan, Z. A.; Ozturk, L.; Bilge, O.; Ozer, M. A. \& Pinar, Y. A. Cadaveric study of the anatomic variations of the brachial plexus nerves in the axillary region and arm. Turk. J. Med. Sci., 31:147-50, 2001.

Chiarapattanakom, P.; Leechavengvongs, S.; Witoonchart, K.; Uerpairojkit, C. \& Thuvasethakul, P. Anatomy and internal topography of the musculocutaneous nerve: the nerves to the biceps and brachialis muscle. J. Hand Surg., 23: 250-5, 1998.

Choi, D.; Rodriguez-Niedenfuhr, M.; Vazquez, T.; Parkin, I. \& Sanudo, J. R. Patterns of connection between the musculocutaneous and median nerves in the axilla and arm. Clin. Anat., 15:11-7, 2002.

Das, S \& Paul, S. Anomalous branching pattern of lateral cord of brachial plexus. Int. J. Morphol., 23(4):289-92, 2005.

Guerri-Guttenberg, R. A. \& Ingolotti, M. Classifying Musculocutaneous Nerve Variations. Clin Anat., 22: 671-83, 2009.

Kervancioglu, P.; Orhan, M. \& Kilinc, N. Pattern of motor branching of the musculocutaneous nerve in human fetuses and clinical significance. Clin. Anat., 24:168-78, 2011.

Kosugi, K.; Shibata, S. \& Yamashita, H. Supernumerary head of biceps brachii and branching pattern of the musculocutaneus nerve in Japanese. Surg. Radiol. Anat., 14(2):175-85, 1992.

Linell, E. A. The distribution of nerves in the upper limb, with reference to variabilities and their clinical significance. $J$. Anat., 55:79 -112, 1921.

Leis, A. \& Wells, K. Radial nerve cutaneous innervation to the ulnar dorsum of the hand. Clinical Neurophysiology, 119: 6626, 2008.
Le Minor, J. M. A rare variation of the median and musculocutaneous nerves in man. Arch. Anat. Histol. Embryol., 73: 33-42, 1990

Loukas, M. \& Aqueelah, H. Musculocutaneous and median nerve connections within, proximal and distal to the coracobrachialis muscle. Folia Morphol (Warsz) 64:101-8, 2005.

Loukas, M.; Shane Tubbs, R. \& Stewart, D. An Abnormal Variation of the Brachial Plexus with Potential Clinical Significance. West Indian Med. J. 57(4):403-5, 2008a.

Loukas, M.; Louis, R. G. Jr.; Wartmann, C. T.; Shane Tubbs, R.; Turan-Ozdemir, S. \& Kramer, J. The clinical anatomy of the communications between the radial and ulnar nerves on the dorsal surface of the hand. Surg. Radiol. Anat., 30: 85-90, 2008b.

Moore, K. L. \& Dalley, A. F. Clinically oriented anatomy. 5th Ed., Baltimore, Lippincott Williams and Wilkins, 2006. pp. 794, 819-822.

Nakatani, T.; Tanaka, S. \& Mizukami, S. Absence of the musculocutaneous nerve with innervation of coracobrachialis, biceps brachii, brachialis and the lateral border of the forearm by branches from the lateral cord of the brachial plexus. $J$. Anat., 191:459-60, 1997.

Nayak, S. Absence of musculocutaneous nerve associated with clinically important variations in the formation, course and distribution of the median nerve - a case report. Neuroanatomy, $6 ;: 49-50,2007$.

Pandey, S. K. \& Shukla, V. K. Anatomical Variations of the Cords of Brachial Plexus and the Median Nerve. Clin Anat., 20:150 $156,2007$.

Pick, J. The Autonomic Nervous System. Morphological Comparative, Clinical and Surgical Alternate Sympathetic Pathways. Philadelphia, J. B. Lippincott, 1970. p. 207. 
Pohlman, A. G. Multiple anomalies in one cadaver. J. Anat. Physiol., 42 (Pt 4):433-7, 1908.

Pontell, M.; Scali, F. \& Marshall, E. A Unique Variation in the Course of the Musculocutaneous Nerve. Clin Anat., Mar 24. doi: 10.1002/ca.21173. [Epub ahead of print], 2011.

Prasada Rao, P. V. V. \& Chaudhary, S. C. Absence of musculocutaneous nerve: two case reports. Clin Anat., 14:315,2001 .

Roberts, W. H. Anomalous course of the median nerve medial to the trochlea and anterior to the medial epicondyle of the humerus. Anat. Anz., 174:309-11, 1992.

Romanes, G. J. Cunningham's textbook of anatomy. 12th Ed. London, Oxford University Press, 1991, pp. 774 -826.

Rosse, C. \& Gaddum-Rosse, P. Hollinshead's textbook of anatomy. 5th Ed. Philadelphia, Lippincott-Raven, 1997, p. 255.

Saeed, M. \& Rufai, A. A. Median and Musculocutaneous Nerves: Variant Formation and Distribution. Clin. Anat., 16:453-7, 2003.

Sargon, M. F.; Uslu, S. S.; Celik, H. H. \& Aksit, D. A variation of the median nerve at the level of brachial plexus. Bull. Assoc. Anat. (Nancy), 79:25-6, 1995.

Sinnatamby, C. S. Last's Anatomy: Regional and Applied. 11th Ed. Edinburgh, Churchill Livingstone, 2006. pp. 55-57.

Standring, S.; Gray Ellis, H. et al. Gray's Anatomy. 39th Ed. New York, Churchill Livingstone, 2005. p.p. 848, 864, 885-886.

Sunderland, S.; Marshall, R. D \& Swaney, W. E. The intraneural topography of the circumflex, musculocutaneous and obturator nerves. Brain, 82:116 -29, 1959.

Tsikaras, P D.; Agiabasis, A. S. \& Hytiroglou, P. M. A variation in the formation of the brachial plexus characterized by the absence of $\mathrm{C} 8$ and $\mathrm{T} 1$ fibers in the trunk of the median nerve. Abstract. Bull. Assoc. Anat. (Nancy), 67:501-5, 1983.

Uyaroglu, F. G.; Kayalioglu, G. \& Ertürk, M. Anastomotic branch from the median nerve to the musculocutaneous nerve. Anatomy, 2:63-6, 2008.

Venieratos, D, Anagnostopoulou, S. Classification of communications between the musculocutaneous and median nerves. Clin. Anat., 11:327-31, 1998.

Yang, Z. X.; Pho, R. W.; Kour, A. K. \& Pereira, B. P. The musculocutaneous nerve and its branches to the biceps and brachialis muscles. J. Hand Surg. Am., 20:671-5, 1995.
Correspondence to:

Professor K. S. Satyapal

Department of Clinical Anatomy

College of Health Sciences

Faculty of Health Sciences

School of Medical Sciences

University of KwaZulu-Natal

Private Bag X54001

Durban

4000

SOUTH AFRICA

Telephone + 27312607195

Fax number+ 27312607890

E-mail: satyapalk@ukzn.ac.za

Received: 02-09-2011

Accepted: 26-12-2011 